\title{
PHYSICAL FITNESS AND BIRTH WEIGHT IN YOUNG MEN FROM MAPUTO CITY, MOZAMBIQUE
}

\author{
APTIDÃO FÍSICA E PESO AO NASCER EM JOVENS DA CIDADE DE MAPUTO, MOÇAMBIQUE
}

APTITUD FÍSICA Y PESO AL NACER EN HOMBRES JÓVENES DE LA CIUDAD DE MAPUTO, MOZAMBIQUE



Original Article

ARTIGO ORIGINAL

Artículo Original
Mario Eugénio Tchamo' (Physical Educator)

Marcos André de Moura dos Santos ${ }^{2,4}$ (Physical Educator)

Marcelus Brito de Almeida² (Physical Educator)

António Manuel Machado Prista e Silva' (Physical Educator)

Carol Góis Leandro 2,3

(Physical Educator)

1. University of Maputo-Mozambique, Pedagogic Research Group for Physical Activity and Health (CIDAF), Maputo, Mançambique.

2. Universidade Federal de Pernambuco, CAV, Department of Physical Education and Sports Science, Recife, PE, Brazil.

3. Universidade Federal de Pernambuco, Department of Nutrition, Recife, PE, Brazil. 4. Universidade de Pernambuco, ESEF-UPE. Recife, PE, Brazil.

\section{Correspondência:}

Carol Góis Leandro

Universidade Federal de Pernambuco (CAV-UFPE). Recife, PE, Brasil.

Rua Alto do Reservatório, S/N Bela Vista, Vitória de Santo Antão, PE, Brasil. 55608-680.

carolleandro22@yahoo.com.br

\begin{abstract}
Introduction: Birth weight has been considered an important marker of the nutritional transition in developing countries. Objective: To evaluate the influence of birth weight on body composition and physical fitness of young men born in Maputo, Mozambique. Methods: One hundred and seventy-nine students (aged 19 to 22 years) were divided into four groups (low birth weight $<2.500 \mathrm{~g}, \mathrm{LBW}, \mathrm{n}=49$; insufficient birth weight $\geq 2.500 \mathrm{~g}$ and $<3.000 \mathrm{~g}, \mathrm{BWW}, \mathrm{n}=27$; normal birth weight $\geq 3.000 \mathrm{~g}$ and $<3.999 \mathrm{~g}, \mathrm{NBW}, \mathrm{n}=74$; and high birth weight $>3.999 \mathrm{~g}, \mathrm{HBW}, \mathrm{n}=31$ ). Anthropometry and body composition were measured. Physical fitness was assessed by handgrip strength, muscle endurance, flexibility, agility, and running speed. Results: IBW showed lower values of body mass and fat free mass while LBW and HBW had high values of hip circumference, suprailiac, subscapular and abdominal skinfold when compared to NBW. LBW and HBW showed a high percentage of individuals with low performance in flexibility, right handgrip, agility, abdominal resistance, arms strength, and horizontal long jump. Around $70 \%$ of HBW showed low performance in the running speed test. Conclusion: Both low and high birth weight can influence adult adiposity and the performance in physical fitness tests.
\end{abstract}

Keywords: muscular strength, physical fitness, birth weight, young adult.

\section{RESUMO}

Introdução: O peso ao nascer tem sido considerado um marcador importante da transição nutricional nos países em desenvolvimento. Objetivo: Avaliar a influência do peso ao nascimento na composição corporal e aptidão física de homens jovens nascidos em Maputo, Moçambique. Métodos: Cento e setenta e nove estudantes (com idades entre 19 a 22 anos) foram divididos em quatro grupos (baixo peso ao nascer <2.500 g, BPN, $n=49$; peso insuficiente ao nascer $\geq 2.500 \mathrm{ge}<3.000 \mathrm{~g}$, PIN, $n=27$; peso normal ao nascer $\geq 3.000 \mathrm{ge}<3.999 \mathrm{~g}, P N \mathrm{~N}, n=74$; e peso elevado ao nascer $>3.999 \mathrm{~g}, P E N, n=31)$. Foram avaliadas a antropometria e a composição corporal. A aptidão física foi avaliada por testes de força de preensão manual, resistência muscular, flexibilidade, agilidade e velocidade de corrida. Resultados: PIN mostrou menores valores de massa corporal e massa livre de gordura, enquanto BPN e PEN apresentaram altos valores de circunferência do quadril, supra-ilíaca, subescapular e dobra cutânea abdominal quando comparados com PNN. BPN e PEN mostraram um alto percentual de indivíduos com baixo desempenho em termos de flexibilidade, preensão palmar direita, agilidade, resistência abdominal, força de braço, e salto em distância horizontal. Cerca de $70 \%$ dos PEN apresentaram baixo desempenho no teste de velocidade de corrida. Conclusão: Ambos baixo e alto peso ao nascer podem influenciar a adiposidade no adulto e o desempenho em testes de aptidão física.

Descritores: força muscular, aptidão física, peso ao nascer, adulto jovem.

\section{RESUMEN}

Introducción: El peso al nacer ha sido considerado un importante marcador de la transición nutricional en los países en desarrollo. Objetivo: Evaluar la influencia del peso al nacer en la composición corporal y la aptitud física de los jóvenes nacidos en Maputo, Mozambique. Métodos: Ciento setenta y nueve estudiantes (de 19 a 22 años) se dividieron en cuatro grupos (bajo peso al nacer $<2.500 \mathrm{~g}, B P N, n=49$; peso insuficiente al nacer $\geq 2.500 \mathrm{~g} y<$ $3.000 \mathrm{~g}$, PIN, $n=27$; peso normal al nacer $\geq 3.000 \mathrm{~g}$ y $<3.999 \mathrm{~g}, P N \mathrm{~N}, n=74$; $y$ peso elevado al nacer $>3.999 \mathrm{~g}$, PEN, $n=31$ ). Se evaluó la antropometría y composición corporal. La aptitud física se evaluó mediante la fuerza de prensión, resistencia muscular, flexibilidad, agilidad y velocidad de carrera. Resultados: PIN mostró valores más bajos de masa corporal y masa libre de grasa, mientras que el BPN y PEN tenían valores altos de circunferencia de la cadera, suprailiaco, subescapular y pliegue abdominal en comparación con PNN. BPN y HBW mostraron un alto porcentaje de personas con bajo rendimiento en flexibilidad, fuerza de prensión de la mano derecha, agilidad, resistencia abdominal, fuerza de los brazos, y salto de longitud horizontal. Alrededor del 70\% de HBW mostró bajo rendimiento en la prueba de velocidad de carrera. Conclusión: Tanto bajo y alto peso al nacer pueden influir en la obesidad de adultos y el desempeño en las pruebas de aptitud física.

Descriptores: fuerza muscular, aptitud física, peso al nacer, adulto joven. 


\section{INTRODUCTION}

During the period of 1980 to 1992, a civil war began in Mozambique placing it among the poorest countries in the world with serious socioeconomic problems ${ }^{1}$. This situation that harried Mozambique was also characterized by food restrictions and a lack of consumables ${ }^{2}$. After the peace agreement of 1992, there was an improvement in the urbanization, sedentary occupations, availability of private transport and to the advent of "fast food", particularly in the capital, Maputo". Mozambican children who were born and growing under that war environment presented changes in the pattern of height and weight per age as seen in previous studies ${ }^{2}$. Prista et al. ${ }^{2}$ compared the growth status of a sample of school children, measured just after the end of civil war (in 1992), with a sample of school children 7 years after war (1,098 boys and 1,173 girls, age 6-17 years). Height, weight, BMl, fat mass, and lean body mass were always higher in the sample ( 7 years later civil war) than in the children evaluated in 1992, showing the recovery of growth status after the war.

According to previous study, Mozambique has passed for a nutritional transition since the prevalence of stunting has decreased dramatically in Maputo schoolchildren while the prevalence of overweight has increased ${ }^{2}$. Over the period of 1992 to 2000, the proportion of subjects with stunted growth dropped from $34.5 \%$ to $3 \%$ in males and from $24.6 \%$ to $2.3 \%$ in females, whereas the proportion of overweight subjects increased from $0 \%$ to $4.8 \%$ in males and from $4.9 \%$ to $7.7 \%$ in females ${ }^{3}$. This scenario of nutritional transition has been shared among low and middle-income countries that are accompanied by demographic and epidemiological transition associated with economic development and urbanization ${ }^{4}$. Birth weight has been considered an important marker of the nutritional transition because; both infant obesity and adult short stature were associated with fetal growth and the range of birth weight ${ }^{5}$. High levels of physical inactivity and sedentary lifestyle have also been associated with the nutrition transition in several countries ${ }^{6}$.

Focusing on life-course plasticity, a large number of epidemiological studies have shown that the birth weight and the low level of nutritional intake early life followed by alterations in growth trajectory and metabolism, may impact on subsequent obesity risk ${ }^{5,7}$. There is an inverse association between low birth weight $(<2,500 \mathrm{~g})$ and risk of the metabolic syndrome ${ }^{8}$. Likewise, excessive birth weight $(>4,000 \mathrm{~g})$ was associated with increased risk of obesity $(\mathrm{OR}, 2.07 ; 95 \%, \mathrm{Cl}=1.91$ to 2.24$)^{9}$. In terms of motor performance, birth weight was considered an important determinant of the variance of neuromotor development in children ${ }^{10}$ and an inducer of permanent deficits in muscle strength and running speed performance ${ }^{11}$.

However, little is known about the effects of low birth weight on physical fitness in young men. Our hypothesis is that birth weight is a lifespan predictor of body fat, fat-free-mass and physical fitness in the direction of high fat mass accumulation and low level of physical fitness. Thus, our main goal was to evaluate the influence of birth weight on the anthropometry, body composition and physical fitness of young men. Ours findings suggest that extreme of birth weight (low and high) can influence body composition and the performance of some physical fitness tests.

\section{MATERIAL AND METHODS}

This study was conducted in the Maputo city, capital of Mozambique, a traditionally low-income region in Africa. A total of 179 male students (aged 19 to 22 years), born in Maputo-Mozambique, were divided into four groups according to their birth weight (low birth weight $<2.500 \mathrm{~g}, \mathrm{LB}, \mathrm{n}=49$, insufficient birth weight $\geq 2.500 \mathrm{~g}$ and $<3.000 \mathrm{~g}$, IBW: $n=27$, normal birth weight $\geq 3.000 \mathrm{~g}$ and $<3.999 \mathrm{~g}$,
NBW, $n=74$; and high birth weight $>3.999 \mathrm{~g}, \mathrm{HBW}, \mathrm{n}=31$ ). Birth weight was obtained from the health booklets in which this information was recorded by nurses and/or pediatricians. Written Informed Consent was obtained from the participants and the study was approved by the Ethical Committee of the local health authority (National Committee of Bioethics for Health, protocol number Ref.74/CNBS).

Height and sitting height erect was measured to the nearest $1.0 \mathrm{~cm}$ using a portable stadiometer (Holtain, Crymych, United Kingdom) with the participant's head positioned in the Frankfurt horizontal plane ${ }^{12}$. Bodyweight was measured to the nearest $0.1 \mathrm{~kg}$ with a digital scale (M 01-22-07-245; Secca, Germany). Body mass index (BMI) was calculated using the standard formula [weight $(\mathrm{kg}) /$ height $\left.^{2}(\mathrm{~m})\right]$. Triceps and subscapular skinfolds were measured with a Langer caliper (Lange, Santa Cruz, California, USA). Body fat percentage, fat mass (Kg) and fat free mass $(\mathrm{Kg})$ were calculated using the formulas described in previous studies ${ }^{13}$. All measurements were done according to the procedures outlined in previous study ${ }^{13}$. The arm and leg circumference was obtained with a flexible tape measure with precision of $0.1 \mathrm{~cm}$, according to the conventional techniques. Hip circumference was measured at the widest point between the buttocks and the iliac crest. Waist circumference was measured at the midpoint between the lower ribs and the iliac crest in accordance with standard procedures ${ }^{14}$.

Physical fitness was assessed according to FITNESSGRAM and EUROFIT standardized test batteries, including: (1) handgrip strength (measured in each hand independently using a hand-grip dynamometer (Saehan, Flintvile, USA); (2) standing long jump (expressing the explosive power of lower limbs); (3) "curl-ups" (as an indicator of dynamic muscle endurance); (4) "sit and reach" as a measure of flexibility; (4) square test (time to travel a distance in a square with $4 \times 4$ meters with changes in direction) as a measure of agility; (5) 20-meter run measuring speed.

The performance of each test was analyzed and it was divided in tercis of performance, thus, three categories were formed: $<25 \%$ low performance, $50 \%$ median, and $>75 \%$ high performance. It was taken these values to analyze the performance of the groups and results were expressed in percentage into the categories as well as the absolute number of subjects.

\section{Statistical analysis}

Statistical analysis was conducted with SPSS (SPSS Inc., Chicago, IL), version 17.0 and Graphpad Prism 5.0 programs. Exploratory data analysis was used to identify possible inaccurate information and the presence of outliers and to test the assumption of normality in all data distributions. Kolmogorov-Smirnov and Shapiro-Wilk normality tests were applied in total sample. For data with normal distribution was used analysis of variance (ANOVA). Post hoc examinations were conducted with Bonferroni post-hoc test. Nonparametric data were analyzed by using Mann-Whitney $U$ test. Statistical significance was set at $P<0.05$ for all analysis.

\section{RESULTS}

Descriptive analyses of anthropometry and body composition of the total sample are shown in Table 1.

When sample were divided according to the birth weight, anthropometry and body composition were not different among groups (Table 2). Exception was seen for IBW group that showed lower values of body mass and fat free mass than NBW.

LBW and HBW showed high values of hip circumference when compared to NBW (Figure 1A). The hip/waist ratio was not different among groups (NBW $=0.78 \pm 0.3 ; \mathrm{LBW}=0.77 \pm 0.2 ; \mathrm{IBW}=0.76 \pm 0.3$; 
Table 1. Total sample descriptive characteristics (Means \pm SEM, minimum and maximum) of physical growth, body composition and physical fitness variables.

\begin{tabular}{c|c|c|c}
\hline & $\begin{array}{c}\text { Mean } \mathbf{\pm} \mathbf{s d} \\
(\mathbf{n}=\mathbf{1 7 9})\end{array}$ & Min & Max \\
\hline Birth Weight (g) & $3170 \pm 0.052$ & 1000 & 5000 \\
\hline Age (years) & $18.8 \pm 0.09$ & 17.0 & 22.0 \\
\hline Growth and Body Composition & & & \\
\hline Weight (Kg) & $61.1 \pm 0.58$ & 42.0 & 84.0 \\
\hline Height (cm) & $171.0 \pm 0.50$ & 151.0 & 194.0 \\
\hline BMl (Kg.m $\left.{ }^{-2}\right)$ & $20.8 \pm 0.15$ & 16.2 & 28.4 \\
\hline Body Fatness (\%) & $22.5 \pm 0.26$ & 15.0 & 35.8 \\
\hline Fat Mass (kg) & $13.9 \pm 0.26$ & 6.3 & 29.6 \\
\hline Fat Free Mass (kg) & $47.2 \pm 0.40$ & 32.9 & 62.3 \\
\hline Waist/Hip & $0.78 \pm 0.002$ & 0.70 & 0.91 \\
\hline
\end{tabular}

Table 2. Descriptive analyses of anthropometry and body composition of young men aged $19-22$ y old divided according to their birth weight. Normal birth weight (NBW), low birth weight (LBW), insufficient birth weight (IBW) and highbirth weight (HBW).

\begin{tabular}{|c|c|c|c|c|c|}
\hline & \multicolumn{4}{|c|}{ Groups } & \\
\hline & NBW & LBW & IBW & HBW & \\
\hline & $(n=72)$ & $(n=48)$ & $(n=27)$ & $(n=31)$ & $p$ \\
\hline Birth weight (kg) & $3.35 \pm 0.23$ & $2.36 \pm 0.27$ & $2.83 \pm 0.10$ & $4.28 \pm 0.32$ & 0.000 \\
\hline Age (years) & $18.9 \pm 1.2$ & $18.9 \pm 1.2$ & $18.3 \pm 0.9$ & $18.8 \pm 1.4$ & 0.098 \\
\hline \multicolumn{6}{|l|}{ Anthropometry } \\
\hline Body mass (Kg) & $62.3 \pm 7.2$ & $60.6 \pm 8.9$ & $57.4 \pm 6.8^{a}$ & $62.2 \pm 7.5$ & 0.044 \\
\hline Body height (cm) & $172.2 \pm 7.3$ & $169.2 \pm 6.7$ & $170.1 \pm 5.9$ & $171.1 \pm 5.2$ & 0.060 \\
\hline $\begin{array}{l}\text { Body Mass Index } \\
\qquad\left(\mathrm{Kg} / \mathrm{m}^{2}\right)\end{array}$ & $20.9 \pm 1.9$ & $20.9 \pm 2.0$ & $20.0 \pm 1.8$ & $21.0 \pm 2.1$ & 0.111 \\
\hline $\begin{array}{l}\text { Seating height } \\
\text { erect }(\mathrm{cm})\end{array}$ & $85.6 \pm 3.8$ & $85.1 \pm 4.0$ & $83.7 \pm 3.5$ & $85.8 \pm 3.7$ & 0.120 \\
\hline \multicolumn{6}{|l|}{ Body Composition } \\
\hline $\begin{array}{c}\sum \text { skinfold triceps and } \\
\text { subscapular }(\mathrm{mm})\end{array}$ & $15.6 \pm 3.6$ & $16.3 \pm 5.1$ & $15.4 \pm 3.7$ & $15.4 \pm 3.1$ & 0.747 \\
\hline Fat mass (\%) & $15.5 \pm 1.1$ & $15.8 \pm 2.3$ & $14.8 \pm 1.4$ & $15.5 \pm 1.7$ & 0.220 \\
\hline Fat mass (Kg) & $9.8 \pm 1.9$ & $9.8 \pm 2.9$ & $8.6 \pm 1.7$ & $9.8 \pm 2.1$ & 0.145 \\
\hline Fat free mass $(\mathrm{Kg})$ & $52.6 \pm 5.4$ & $50.8 \pm 6.3$ & $48.8 \pm 5.2^{\mathrm{a}}$ & $52.4 \pm 5.5$ & 0.025 \\
\hline
\end{tabular}

a $P<0.05$ vs NBW by one-way ANOVA and post-hoc Tukey test.

$\mathrm{HBW}=0.78 \pm 0.2, \mathrm{p}>0.05$ ). Peripheral subcutaneous skinfolds (biceps, triceps and germinal) did not alter among groups (Figure 1B). On the other hand, LBW groups showed high values of central subcutaneous skinfold (suprailiac, subscapular and abdominal) when compared to NBW. HBW group showed higher abdominal skinfold than NBW group (Figure1B).

Physical fitness did not differ when groups were compared, except for HBW group that showed low values for horizontal long jump when compared to NBW (Table 3).

LBW and HBW showed a higher percentage of individuals with a low performance of flexibility, right and left handgrip strength, and

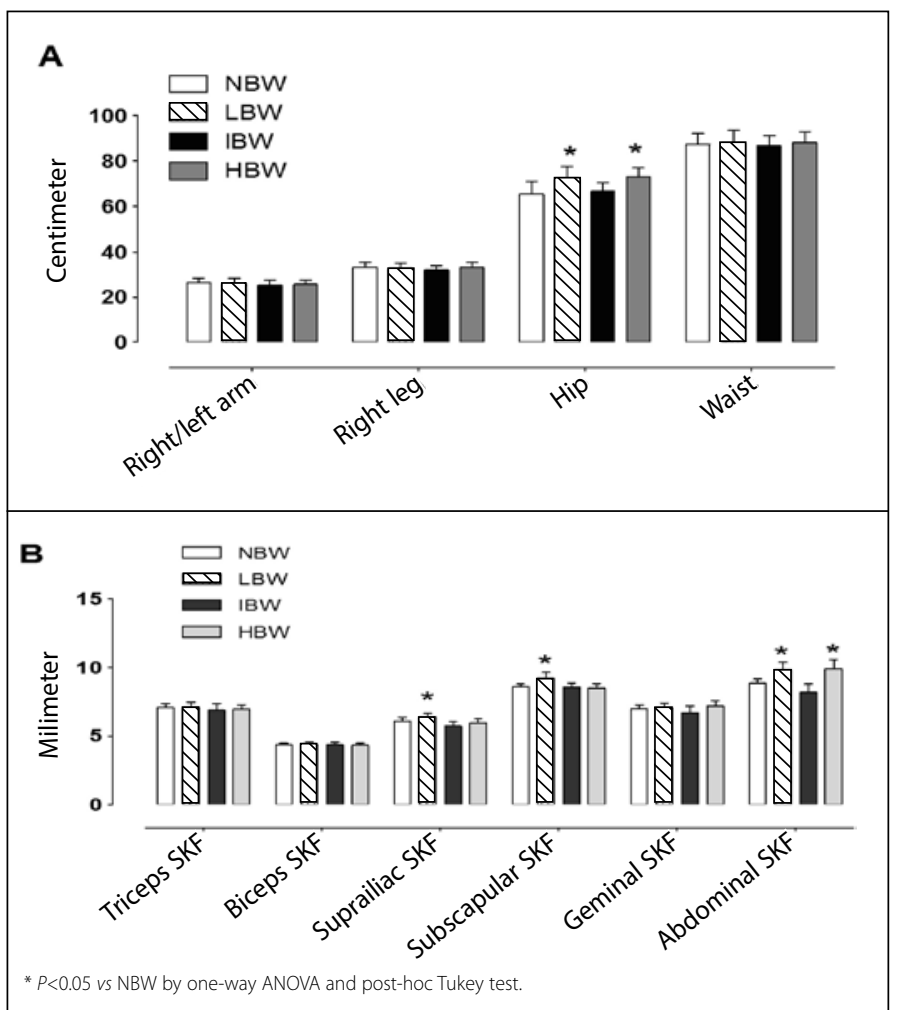

Figure 1. Descriptive analyses of the right/left arm, right leg, hip, and waist circumferences (A) and triceps, biceps, suprailiac, subscapular, germinal and abdominal subcutaneous skinfolds (B) of young men aged 19-22 y old born with normal birth weight (NBW, $n=72)$, low birth weight (LBW, $n=48)$, insufficient birth weight (IBW, $n=27)$ and high birth weight ( $H B W, n=31)$. Values are expressed as means and standard deviations.

Table 3. Descriptive analyses of physical fitness of young men aged 19-22 years old born with normal weight (NBW), low weight (LBW), insufficient weight (IBW) and high weight (HBW). Values are expressed in median (minimal and maximal values).

\begin{tabular}{|c|c|c|c|c|}
\hline & NBW $(n=72)$ & LBW $(n=48)$ & IBW $(n=27)$ & HBW $(n=31)$ \\
\hline & $\begin{array}{c}\text { Median } \\
\text { (Min - Max) }\end{array}$ & $\begin{array}{c}\text { Median } \\
\text { (Min - Max) }\end{array}$ & $\begin{array}{c}\text { Median } \\
\text { (Min - Max) }\end{array}$ & $\begin{array}{c}\text { Median } \\
\text { (Min - Max) }\end{array}$ \\
\hline $\begin{array}{l}\text { Sit and Reach }(\mathrm{cm}) \\
\text { [Flexibility] }\end{array}$ & $\begin{array}{c}36.6 \\
(20-50)\end{array}$ & $\begin{array}{c}33.7 \\
(14-45)\end{array}$ & $\begin{array}{c}36.1 \\
(10-49)\end{array}$ & $\begin{array}{c}33.4 \\
(15-53)\end{array}$ \\
\hline $\begin{array}{l}\text { Time to perform a } \\
\text { distance in a square with } \\
4 \times 4 \text { meters (s) [Agility] }\end{array}$ & $\begin{array}{c}7.6 \\
(5.4-10.3)\end{array}$ & $\begin{array}{c}7.9 \\
(6.0-11.4)\end{array}$ & $\begin{array}{c}7.7 \\
(6.6-9.6)\end{array}$ & $\begin{array}{c}7.9 \\
(5.4-9.1)\end{array}$ \\
\hline $\begin{array}{l}\text { Running speed in } 20 \\
\text { meter test (s) [Speed] }\end{array}$ & $\begin{array}{c}5.2 \\
(3.9-7.0)\end{array}$ & $\begin{array}{c}5.3 \\
(3.4-7.7)\end{array}$ & $\begin{array}{c}5.2 \\
(4.1-6.9)\end{array}$ & $\begin{array}{c}5.6 \\
(3.9-7.0)\end{array}$ \\
\hline Right handgrip (Kgf) & $\begin{array}{c}46.3 \\
(31-59)\end{array}$ & $\begin{array}{c}44.9 \\
(32-71)\end{array}$ & $\begin{array}{c}42.4 \\
(26-54)\end{array}$ & $\begin{array}{c}44.3 \\
(27-62)\end{array}$ \\
\hline Left handgrip (Kgf) & $\begin{array}{c}44.3 \\
(30-61)\end{array}$ & $\begin{array}{c}42.3 \\
(28-65)\end{array}$ & $\begin{array}{c}42.2 \\
(30-58)\end{array}$ & $\begin{array}{c}42.2 \\
(28-55)\end{array}$ \\
\hline $\begin{array}{c}\text { Curl-Ups } \\
\text { (n } n^{\circ} \text { of repetitions/min) }\end{array}$ & $\begin{array}{c}34 \\
(16-66)\end{array}$ & $\begin{array}{c}32.2 \\
(20-76)\end{array}$ & $\begin{array}{c}36 \\
(17-72)\end{array}$ & $\begin{array}{c}34.4 \\
(16-76)\end{array}$ \\
\hline $\begin{array}{l}\text { Standing Long jump } \\
(\mathrm{cm})\end{array}$ & $\begin{array}{c}184.9 \\
(123-260)\end{array}$ & $\begin{array}{c}182.4 \\
(129-226)\end{array}$ & $\begin{array}{c}184.2 \\
(126-229)\end{array}$ & $\begin{array}{c}172.6^{\mathrm{a}} \\
(137-230)\end{array}$ \\
\hline
\end{tabular}

a $P<0.05$ vs NBW by using Kruskall-Wallis test and post-hoc Dunn test.

horizontal long jump. It is interesting to note that HBW individuals showed a high percentage of low performance in all physical fitness tests except for arm strength. LBW and HBW groups showed a higher percentage of low performance in abdominal resistance, arms strength, and horizontal long jump. Around 30 - 40\% of young men from LBW, IBW and HBW showed a low performance in the curl-up test (Figure 2A-B). 



Figure 2. Frequency analyses of the performance in each test of physical fitness. Young men born with normal weight (NBW, $n=72$ ) were divided in tercis of performance in each physical fitness test ( $>25 \%$ low performance, 50\% median, and $<75 \%$ high performance). Low birth weight (LBW, $n=48$ ), insufficient birth weight $(\mathrm{BWW}, \mathrm{n}=27)$ and high birth weight (HBW, $n=31)$.Values are expressed in percentage into each categories of tercis from NBW.

\section{DISCUSSION}

Experimental and clinical studies have linked the birth weight and early disturbs during child development with the risk of degenerative diseases such as stroke, hypertension, obesity and type 2 diabetes in adult life ${ }^{15,16}$. In human, these observations were replicated in both from industrialized countries ${ }^{7}$ and also those undergoing the nutritional transition ${ }^{17,18}$. In African countries, previous studies have shown the effects of birth weight on growth and development during childhood ${ }^{19}$. For example, in Keneba, the Gambia, birth weight have been inversely associated with impaired adult bone strength, male and female 7 to 21 years ${ }^{20}$. Fetal size was also inversely related to systolic blood pressure in childhood in Zimbabwe and in South Africa ${ }^{21}$. Due to its historical background, it is important to consider the influence of birth weight (low, insufficient and excessive) on the body composition and physical fitness of young men from Maputo, Mozambique. For our knowledge, this is the first study that considered motor performance susceptible to early events in life in a sample from Mozambique.

We found that our sample presented a normal BMI (> 20 and < 25) and normal mean values of anthropometric and body composition according to the National Centre for Health Statistics standards. However, in the present study, insufficient birth weight influenced significantly for a lower adult weight and fat free mass. This influence is aligned with previous studies ${ }^{22}$. Similarly, the differences in the hip and abdominal skinfold thicknesses, as well as in the indices of central fat distribution (waist-hip and skinfold ratios) seen in the LBW and HBW are in accordance with earlier findings ${ }^{17,23}$. It seems that both low and excessive birth weight can predict more strongly adult adiposity than adult lean mass. One of the best-known attempts to understand this central riddle of the association between birth weight and late risk of fat accumulation is the "phenotype thrifty hypothesis" proposed by Hales and Barker ${ }^{24}$. This hypothesis proposed that perinatal stimuli/ insults (for example, malnutrition, smoke, antigens, drugs and alcohol) induces physiological and metabolic adaptations in a short-term, but with later consequences on the risk of obesity, diabetes type 2, hypertension and metabolic diseases ${ }^{25}$. However, the thrifty phenotype hypothesis emphasized the role developmental experience in shaping subsequent metabolism, in-dependent of genotype. The mechanism described above may involve either genetic adaptation, or mechanisms of plasticity, and at this stage neither can be ruled out ${ }^{25}$.

Recently, it was proposed a new theoretical model for cardiovascular disease risk highlighting birth weight as an index of 'metabolic capacity' (organ structure and function that emerge during fetal life and infancy promoting the maintenance of homeostasis), and several factors in childhood (large tissue masses, sedentary behavior and high-fat diet) as indices of 'metabolic load' that challenge the ability to maintain homeostasis ${ }^{26}$. According to this model, body size and adiposity are predicted to increase metabolic load, whereas low birth weight is predicted to reduce metabolic capacity ${ }^{26}$. Metabolic load may be further exacerbated by sedentary behavior, which is associated with impaired motor performance during childhood with repercussions for young men.

In the present study, birth weight did not influence mean values of physical fitness performance in young men except for standing long jump in the HBW group. In contrast with our findings, previous studies have shown that LBW subjects aged 10-20 y have lower performance in tests for physical fitness assessment when compared to normal birth weight control subjects ${ }^{27,28}$. However, when it was not considered the mean values but the individual performance, the extreme of birth weight (LBW and $\mathrm{HBH}$ ) showed a high percentage of individual with low performance. Thus, when groups were also analyzed in terms of performance categories, and it was found that high birth weight strongly influenced the performance in all physical fitness tests except for arm strength. More than $50 \%$ of individuals born with high weight showed a low performance in the horizontal long jump. This result can be related to the phenotype changes in skeletal muscle development as seen in both animals and human beings. In previous study, 20 healthy 19 -yr-old men with low birth weight presented $+66 \%$ of type IIx at expense of decreased type lla fibers $(-22 \%)^{29}$. In animals, LBW pups showed a reduced oxidative fibers (type I) and increased glycolytic fiber (type Ilb) in adult animals ${ }^{30}$. Additional studies with more detailed parameters of metabolic and structural analysis would help to understand the mechanisms by which adverse environmental stimuli, here represented by birth weight, may affect physical performance later in life.

Physical fitness is often related to components such as cardiovascular fitness, muscular strength and endurance, body composition and flexibility. Studies involving physical fitness have analyzed its relationship with the risks for chronic diseases ${ }^{31,32}$. For instance, higher cardiorespiratory fitness has been associated to lower predisposition to cardiovascular and metabolic diseases ${ }^{31}$, overweight, hypercholesterolaemia, and hypertension ${ }^{32}$. Muscular strength and endurance are related to lower risks for heart disease, enhance of lean mass, reduced incidence of low back pain, osteoarthritis, osteoporosis and risk of injuries ${ }^{31}$. In addition, flexibility has been related to benefits such as reduced injury risk, prevention or reduction of post-exercise soreness ${ }^{33}$. Both LBW and HBW could result directly in reduced physical fitness including reduced muscle strength due to low muscle mass, and an insufficient aerobic capacity related to low cardiorespiratory fitness in young adult ${ }^{6}$. 


\section{CONCLUSION}

Low and middle-income countries have experienced a rapid economic and urbanization development, and nutritional transition that can be considered the major compelling force behind the risk of obesity-related diseases. In the present study, we found that both low and high birth weight can predict more strongly adult adiposity. The high percentage of subjects with low performance in flexibility, right handgrip, and agility tests was seen in LBW and HBW subjects. Thus, the extreme of birth weight (low and high) can influence body composition and the performance of some physical fitness tests.

\section{ACKNOWLEDGMENTS}

Authors' contributions were as follows: MET, AP and CGL designed the study and collected the data. MET, MAMS, MBA, AP, and CGL performed all statistical analyses and wrote the paper. All authors were responsible for critical revisions of the paper and approval of the final version. We thank all young men and their families for participating in this study.

All authors have declared there is not any potential conflict of interests concerning this article.

CONTRIBUIÇÕES DOS AUTORES: All authors contributed individually and significantly for this multi-institutional study. MET(0000-0003-3808-1240)* AP and CGL participated actively in the conduction of the study, data analysis and revision of the manuscript. MBA(0000-0001-7286-7736)* and MAM (0000-0002-2734-8416)* participated in the data analysis and revision of manuscript. MET and CGL (0000-0001-6176-1688)* conducted the process of revision and final version of the study. *ORCID Number (Open Researcher and Contributor ID).

\section{REFERENCES}

1. Padez C, Varela-Silva MI, Bogin B. Height and relative leg length as indicators of the quality of the environment among Mozambican juveniles and adolescents. Am J Hum Biol. 2009;21(2):200-9.

2. Prista A, Maia AJ, Saranga S, Nhantumbo L, Marques AT, Beunen G. Somatic growth of a school-aged population from Mozambique: trend and biosocial meaning. Hum Biol. 2005;77(4):457-70.

3. Prista A, Maia JA, Damasceno A, Beunen G. Anthropometric indicators of nutritional status: implications for fitness, activity, and health in school-age children and adolescents from Maputo, Mozambique Am J Clin Nutr. 2003;77(4):952-9.

4. Atinmo T, Mirmiran P, Oyewole OE, Belahsen R, Serra-Majem L. Breaking the poverty/malnutrition cycle in Africa and the Middle East. Nutr Rev. 2009;67(Suppl 1):S40-6

5. Barker DJ, Eriksson JG, Forsén T, Osmond C. Fetal origins of adult disease: strength of effects and biological basis. Int J Epidemiol. 2002;31(6):1235-9.

6. Andersen LG, Angquist L, Gamborg M, Byberg L, Bengtsson C, Canoy D, et al. Birth weight in relation to leisure time physical activity in adolescence and adulthood: meta-analysis of results from 13 nordic cohorts. PLoS One. 2009:4(12):e8192.

7. Gluckman PD, Seng CY, Fukuoka H, Beedle AS, Hanson MA. Low birthweight and subsequent obesity in Japan. Lancet. 2007;369(9567):1081-2.

8. Gluckman PD, Hanson MA. The developmental origins of the metabolic syndrome. Trends Endocrinol Metab. 2004;15(4):183-7.

9. Yu ZB, Han SP, Zhu GZ, Zhu C, Wang XJ, Cao XG, et al. Birth weight and subsequent risk of obesity: a systematic review and meta-analysis. Obes Rev. 2011;12(7):525-42.

10. Lopes AA, Tani G, Katzmarzyk PT, Thomis MA, Maia JA. Association between birth weight and neuromotor performance: a twin study. Scand J Med Sci Sports. 2014;24(3):e140-7.

11. Moura-Dos-Santos MA, De Almeida MB, Manhães-De-Castro R, Katzmarzyk PT, Maia JA, Leandro CG. Birthweight, body composition, and motor performance in 7- to 10-year-old children. Dev Med Child Neurol. 2015;57(5):470-5.

12. Lohman TG. Applicability of body composition techniques and constants for children and youths Exerc Sport Sci Rev. 1986;14:325-57.

13. Lohman TG, Going SB. Body composition assessment for development of an international growth standard for preadolescent and adolescent children. Food Nutr Bull. 2006;27(Suppl Growth Standard 4):S314-25.

14. Callaway CW. New weight guidelines for Americans. Am J Clin Nutr. 1991;54(1):171-4.

15. Ozanne SE. Metabolic programming in animals. Br Med Bull. 2001;60:143-52.

16. Gluckman PD, Hanson MA, Bateson P, Beedle AS, Law CM, Bhutta ZA, et al. Towards a new developmental synthesis: adaptive developmental plasticity and human disease. Lancet. 2009;373(9675):1654-7.

17. Kuzawa CW, Hallal PC, Adair L, Bhargava SK, Fall CH, Lee N, et al. Birth weight, postnatal weight gain and adult body composition in five low and middle income countries. Am J Hum Biol. 2012;24(1):5-13.

18. Moura-Dos-Santos M, Wellington-Barros J, Brito-Almeida M, Manhães-de-Castro R, Maia J, Góis Leandro
C. Permanent deficits in handgrip strength and running speed performance in low birth weight children Am J Hum Biol. 2013;25(1):58-62

19. Kimani-Murage EW. Exploring the paradox: double burden of malnutrition in rural South Africa. Glob Health Action. 2013;6:19249.

20. de Bono S, Schoenmakers I, Ceesay M, Mendy M, Laskey MA, Cole TJ, et al. Birth weight predicts bone size in young adulthood at cortical sites in men and trabecular sites in women from The Gambia. Bone. 2010;46(5):1316-21. doi:

21. Levitt NS, Lambert EV, Woods D, Hales CN, Andrew R, Seckl JR. Impaired glucose tolerance and elevated blood pressure in low birth weight, nonobese, young south african adults: early programming of cortisol axis. J Clin Endocrinol Metab. 2000;85(12):4611-8.

22. Labayen I, Moreno LA, Blay MG, Blay VA, Mesana MI, González-Gross M, et al. Early programming of body composition and fat distribution in adolescents. J Nutr. 2006;136(1):147-52.

23. Thomas N, Grunnet LG, Poulsen P, Christopher S, Spurgeon R, Inbakumari M, et al. Born with low birth weight in rural Southern India: what are the metabolic consequences 20 years later? Eur J Endocrinol. 2012;166(4):647-55

24. Hales CN, Barker DJ. Type 2 (non-insulin-dependent) diabetes mellitus: the thrifty phenotype hypothesis Diabetologia. 1992:35(7):595-601.

25. Hales CN, Barker DJ. The thrifty phenotype hypothesis. Br Med Bull. 2001;60:5-20

26. Wells JC. Maternal capital and the metabolic ghetto: An evolutionary perspective on the transgene rational basis of health inequalities. Am J Hum Biol. 2010;22(1):1-17.

27. Kriemler S, Keller H, Saigal S, Bar-Or O. Aerobic and lung performance in premature children with and without chronic lung disease of prematurity. Clin J Sport Med. 2005;15(5):349-55.

28. Rogers M, Fay TB, Whitfield MF, Tomlinson J, Grunau RE. Aerobic capacity, strength, flexibility, and activity level in unimpaired extremely low birth weight $(<0 r=800 \mathrm{~g})$ survivors at 17 years of age compared with term-born control subjects. Pediatrics. 2005;116(1):e58-65

29. Jensen CB, Storgaard H, Madsbad S, Richter EA, Vaag AA. Altered skeletal muscle fiber composition and size precede whole-body insulin resistance in young men with low birth weight. J Clin Endocrino Metab. 2007:92(4):1530-4

30. Leandro CG, da Silva Ribeiro W, Dos Santos JA, Bento-Santos A, Lima-Coelho CH, Falcão-Tebas F, et al. Moderate physical training attenuates muscle-specific effects on fibre type composition in adult rats submitted to a perinatal maternal low-protein diet. Eur J Nutr. 2012;51(7):807-15.

31. Church TS, LaMonte MJ, Barlow CE, Blair SN. Cardiorespiratory fitness and body mass index as predictors of cardiovascular disease mortality among men with diabetes. Arch Intern Med. 2005;165(18):2114-20.

32. Carnethon MR, Sternfeld B, Schreiner PJ, Jacobs DR Jr, Lewis CE, Liu K, et al. Association of 20-year changes in cardiorespiratory fitness with incident type 2 diabetes: the coronary artery risk development in young adults (CARDIA) fitness study. Diabetes Care. 2009;32(7):1284-8.

33. Hopper D, Deacon S, Das S, Jain A, Riddell D, Hall T, Briffa K. Dynamic soft tissue mobilisation increase hamstring flexibility in healthy male subjects. Br J Sports Med. 2005;39(9):594-8. 